\title{
Ammonium/nitrate ratio in the initial growth of Guaco
}

\section{Proporções de amônio e nitrato no crescimento inicial de guaco}

\author{
Weyla Silva de CARVALHO'; Girlene Santos de SOUZA²; Gildeon Santos BRITO; \\ Victor Gabriel Souza de ALEMIDA ${ }^{4}$; Janderson do Carmo LIMA ${ }^{5}$
}

${ }^{1}$ Graduando em Agronomia, Bolsista PIBIC FAPESB, Centro de Ciências Agrárias, Ambientais e Biológicas, Universidade
Federal do Recôncavo da Bahia, weylacarvalho@hotmail.com
${ }^{2}$ Autor para correspondência Professora Doutora Associada 3, Centro de Ciências Agrárias, Ambientais e Biológicas,
Universidade Federal do Recôncavo da Bahia, Rua Rui Barbosa,710, CEP: 44380-000, Cruz das Almas, Bahia,
girlenessouza50@gmail.com
${ }^{3}$ Graduando em Agronomia, Bolsista PIBIC CNPq, Centro de Ciências Agrárias, Ambientais e Biológicas, Universidade Federal
do Recôncavo da Bahia, gildeon.9772@outlook.com
${ }^{4}$ Graduando em Agronomia, Bolsista PIBIC FAPESB, Centro de Ciências Agrárias, Ambientais e Biológicas, Universidade
Federal do Recôncavo da Bahia, victor.gsa11@gmail.com
${ }^{5}$ Doutroando em recurso Genéticos Vegetais, Universidade Estadual de Feira de Santana, janderson_ufrb@yahoo.com.br

Recebido em: 21-07-2020; Aceito em: 11-09-2020

\begin{abstract}
Guaco is a plant that has secondary metabolites with therapeutic properties of interest in human medicine, mainly due to its action in respiratory tract diseases. Nitrogen is a nutrient that participates in the formation of several compounds considered to be of great importance for plant growth. Its main forms of absorption by plants are ammonium $\left(\mathrm{NH}_{4}{ }^{+}\right)$and nitrate $\left(\mathrm{NO}_{3}{ }^{-}\right)$ions and unbalanced ratios can change plant growth. This study evaluates the effect of $\mathrm{NH}_{4}{ }^{+}$and $\mathrm{NO}_{3}{ }^{-}(100: 0 ; 75: 25 ; 50: 50 ; 25: 75$, and $0: 100)$ ratios in nutrient solution on the initial growth of Guaco plants. Guaco growth was affected by $\mathrm{NH}_{4}^{+}$and $\mathrm{NO}_{3}^{-}$ratios. When $\mathrm{NH}_{4}^{+}$was supplied as the exclusive $\mathrm{N}$ source, Guaco plants reduced dry biomass production, number of leaves, leaf area, specific leaf area, leaf area ratio, total chlorophyll, and chlorophyll $\mathrm{a}$ and $\mathrm{b}$ indexes. Thus, increasing doses of the $\mathrm{NO}_{3}{ }^{-}$ion positively favored the initial growth of Guaco.
\end{abstract}

Additional keywords: ionic interaction; Mikania glomerata; nitrogen; soilless culture.

\section{Resumo}

O guaco é uma planta que apresenta metabólitos secundários com propriedades terapêuticas de interesse na medicina humana, principalmente em função da sua ação em enfermidades do trato respiratório. $O$ nitrogênio é um nutriente de plantas que participa da formação de diversos compostos considerados de grande importância para o crescimento vegetal. As principais formas de absorção pelas plantas são como íons amônio $\left(\mathrm{NH}_{4}^{+}\right)$e nitrato $\left(\mathrm{NO}_{3}{ }^{-}\right)$e a utilização de proporções desbalanceadas pode promover alteração no crescimento das plantas. $\mathrm{O}$ objetivo deste trabalho foi avaliar o efeito de proporções de $\mathrm{NH}_{4}{ }^{+}$e $\mathrm{NO}_{3}{ }^{-}$(100:0; 75:25; 50:50; $25: 75$ e 0:100), em solução nutritiva, no crescimento inicial de plantas de guaco. $O$ crescimento do guaco foi afetado pelas proporções de $\mathrm{NH}_{4}{ }^{+}$e $\mathrm{NO}_{3}$. Verificou-se que quando $0 \mathrm{NH}_{4}{ }^{+}$foi fornecido como fonte exclusiva de $\mathrm{N}$ as plantas de guaco apresentaram redução na produção de fitomassa seca, diminuição do número de folhas, menor área foliar, área foliar especifica, razão de área foliar e índices de clorofila "a", "b" e total. Nesse aspecto, infere-se que doses crescentes do íon $\mathrm{NO}_{3}{ }^{-}$favoreceu positivamente o crescimento inicial do guaco.

Palavras-chave adicionais: cultivo sem solo; interação iônica; Mikania glomerata; nitrogênio

\section{Introduction}

The use of plants for medicinal purposes by the world population is a tradition in different cultures, occurring for centuries and being still expressive in recent years. Besides believing in their efficacy and in a lower health risk than allopathic medicines, people interested in using medicinal plants also consider their easy acquisition and low cost (Penido et al., 2016; Campos et al., 2016).

Guaco (Mikania glomerata) stands out for its secondary metabolites with therapeutic properties of interest in human medicine. It has bronchodilator, antiasthmatic, expectorant, and antitussive properties (Aboy et al., 2002). The main secondary metabolite found in Guaco leaves is coumarin, which has tonic, purifying, and antipyretic actions, besides being appetite stimulant and anti-flu, which was proven in several studies, making this species a potent herbal medicine (Czelusniak, et al., 2012).

Nitrogen $(\mathrm{N})$ is a constituent of several molecules, such as chlorophylls, amino acids, proteins, and enzymes (Taiz et al., 2017). $\mathrm{N}$ is available to plants in different forms, with ammonium $\left(\mathrm{NH}_{4}{ }^{+}\right)$and nitrate $\left(\mathrm{NO}_{3}{ }^{-}\right)$being the mineral forms of $\mathrm{N}$ found in natural conditions (Helali et al., 2010; Taiz et al., 2017). Its 
supply in different ionic forms has complex effects on the growth and metabolic activity of plants (Guo et al., 2012), leading to positive and negative physiological responses (Bartelheimer \& Poschlod, 2014).

Nitrogen fertilization exclusively as nitrate decreases dry mass production in plants that have low capacity to reduce it (Ali et al., 2007). On the other hand, high ammonium levels in cell tissues can be toxic and negatively affect root and shoot growth (Hachiya et al., 2012), causing physiological and nutritional disorders (Holzschuh et al., 2011).

According to Esteban et al. (2016), ammonium can limit plant growth, as its use as the only $\mathrm{N}$ source can cause morphological and physiological problems, reducing growth and causing toxicity to plants. However, ammonium consumes less energy due to its direct insertion in the carbon chain of $\mathrm{N}$ assimilation. Thus, the reduction phases by enzymatic action with energy expenditure are not necessary, as occurs for the nitrate ion that is not directly incorporated into an organic compound (Bittsánszky et al., 2015).

Thus, the productivity of the terrestrial ecosystem can be largely affected by the different effects of ammonium and/or nitrate addition on plant growth (Yan, et al., 2019). Associated with this, the response to $\mathrm{N}$ application is very diverse in plants (Huang et al., 2013) and there is no knowledge about the response of Guaco plants. The use of proper ratios can result in yield gains, as these forms are distinctive in relation to their application costs, potential of volatilization and leaching, process of acidification in the soil, and mainly their absorption by plants (Marouelli et al ., 2014).

Therefore, this study evaluates the effect of $\mathrm{NH}_{4}{ }^{+}$and $\mathrm{NO}_{3}{ }^{-}$ratios in nutrient solution on the initial growth of Guaco plants.

\section{Material and methods}

The experiment was performed in a greenhouse in the experimental area of the Center for Agricultural, Environmental and Biological Sciences (CCAAB) of the Federal University of Recôncavo da Bahia (UFRB), municipality of Cruz das Almas, Bahia state, Brazil $\left(12^{\circ} 40^{\prime} 12^{\prime \prime} \mathrm{S}\right.$ latitude and $39^{\circ} 06^{\prime} 07^{\prime \prime} \mathrm{W}$ longitude, altitude of $220 \mathrm{~m}$ ) from October to December 2019.

The experimental design was completely randomized (CRD) with five repetitions and five ammonium/nitrate ratios $(100: 0 ; 75: 25 ; 50: 50 ; 25: 75$, and $0: 100$ ) (Table 1). Treatments were established using the $\mathrm{N}$ concentration in the solution $\left(210 \mathrm{mg} \mathrm{L}^{-1}\right)$ as reference. The treatments were applied via nutritive solution every seven days after transplanting, totaling seven applications. The nutrient solution proposed by Hoagland and Arnon (1950) was used and modified to the ratios evaluated in the treatments (Table 1). The $\mathrm{pH}$ used was $5.6( \pm 1)$, adjusted with $0.01 \mathrm{HCl}$ or 0.01 $\mathrm{NaOH}$. Salt concentrations of solutions were below 1 atm for all treatments, based on the calculation of the osmotic pressure of the solution.

Guaco seedlings from parent plants were used, propagated through $15 \mathrm{~cm}$ cuttings from their middle third, with the presence of buds. Commercial substrate Tropstrato HT was used for cuttings, which consisted of Pinus bark and expanded vermiculite enriched with macro and micronutrients, added in 200-mL polypropylene cups, and cultivated for 30 days until being ready for transplanting.

Table 1 - Volume $(\mathrm{mL})$ of stock solutions to form $1 \mathrm{~L}$ of modified nutrient solution, using proportions of ammonium and nitrate $\left(\mathrm{NH}_{4}^{+}: \mathrm{NO}_{3}{ }^{-}\right)$.

\begin{tabular}{|c|c|c|c|c|c|}
\hline \multirow[b]{2}{*}{ Stock solutions (1M) } & \multicolumn{5}{|c|}{ Proportions of $\mathrm{NH}_{4}^{+}: \mathrm{NO}_{3}^{-}$} \\
\hline & 100:0 & $75: 25$ & $50: 50$ & $25: 75$ & $0: 100$ \\
\hline $\mathrm{KH}_{2} \mathrm{PO}_{4}$ & 1.00 & 1.00 & 1.00 & 1.00 & 1.00 \\
\hline $\mathrm{NH}_{4} \mathrm{Cl}$ & 15.00 & 11.25 & 7.50 & 3.75 & - \\
\hline $\mathrm{KCl}$ & 5.00 & 1.25 & 5.00 & 3.75 & - \\
\hline $\mathrm{CaCl}_{2}$ & 5.00 & 5.00 & 1.25 & - & - \\
\hline $\mathrm{MgSO}_{4}$ & 2.00 & 2.00 & 2.00 & 2.00 & 2.00 \\
\hline $\mathrm{KNO}_{3}$ & - & 3.75 & - & 1.25 & 5.00 \\
\hline $\begin{array}{l}\mathrm{Ca}\left(\mathrm{NO}_{3}\right)_{2} \\
\text { Micronutrientes ** }\end{array}$ & 1.00 & $\overline{1.00}$ & $\begin{array}{l}3.75 \\
1.00\end{array}$ & $\begin{array}{l}5.00 \\
1.00\end{array}$ & $\begin{array}{l}5.00 \\
1.00\end{array}$ \\
\hline Ferro - EDTA * & 1.00 & 1.00 & 1.00 & 1.00 & 1.00 \\
\hline
\end{tabular}

** Micronutrients solution $\left(\mathrm{g} \mathrm{L}^{-1}\right): \mathrm{H}_{3} \mathrm{BO}_{3}=2.86 ; \mathrm{MnCl}_{2} 4 \mathrm{H}_{2} \mathrm{O}=1.81 ; \mathrm{ZnCl}_{2}=0.10 ; \mathrm{CuCl}_{2}=0.04 ; \mathrm{H}_{2} \mathrm{MoO}_{4} \mathrm{H}_{2} \mathrm{O}=0.02$.

* Iron-EDTA solution: $26.1 \mathrm{~g}$ of disodium EDTA were dissolved in $286 \mathrm{~mL}$ of $1 \mathrm{~N} \mathrm{NaOH}+24.9 \mathrm{~g}$ of FeSO $\mathrm{Fe}_{4} .7 \mathrm{H}_{2} \mathrm{O}$ and aerated overnight. 
Seedlings were transferred to plastic pots $\left(3 \mathrm{dm}^{3}\right)$ containing sand previously sieved in a $4 \mathrm{~mm}$ mesh and washed. The application of treatments started eight days after transplantation (DAT), with addition of $200 \mathrm{~mL}$ of the nutrient solution with half the ionic strength described by Hoagland and Arnon (1950) per pot.

Plants were evaluated at 62 DAT and the following variables were measured: number of leaves (NL); indexes of chlorophyll a (CLA), b (CLB), total (TCL), and a/b ratio; leaf (LDM), stem (SDM), shoot (SHDM), root (RDM), and total (TDM) dry mass; root/shoot ratio (RSR), leaf area (LA), specific leaf area (SLA), and leaf area ratio (LAR).

Chlorophyll indexes were evaluated with the Falker chlorophyll meter (model CFL1030) and the number of leaves was evaluated through counting. Subsequently, plants were partitioned into root, stem, and leaf and packed individually in paper bags subjected to drying at $45{ }^{\circ} \mathrm{C}$ in a forced air circulation oven until reaching constant mass. Dry biomass values were obtained on an analytical scale with precision of $10^{-3}$.

Leaf area was obtained using a perforator with diameter of $6 \mathrm{~mm}$, through which 10 leaf discs were collected from each plant with leaves chosen at random, avoiding the midrib region. Subsequently, discs were dried in the same conditions described and weighed in an analytical scale with precision of $10^{-4}$. Leaf area was estimated after obtaining the dry mass and area of the 10 discs (Peixoto et al., 2011). Leaf area ratio (LAR) and specific leaf area (SLA) were determined from LA/TDM and LA/LDM values, respectively.

The data were subjected to analysis of variance using the R statistical program (R Core Team, 2018), and the Tukey test was applied to means comparison.

\section{Results and discussion}

Ammonium/nitrate ratios interfered in characteristics such as the number of leaves and leaf, stem, shoot, root, and total dry mass, leaf area, leaf area ratio, specific leaf area, and chlorophyll index.

Ammonium as the only $\mathrm{N}$ source compromised negatively chlorophyll a, b, and total indexes of Guaco leaves, with the largest means observed in increasing nitrate ratios from 50:50 $\left(\mathrm{NH}_{4}{ }^{+}: \mathrm{NO}_{3}{ }^{-}\right)$(Table 2). This was possibly due to acidification of the substrate. Treatments with higher ammonium concentrations favored predominance of cations in the solution. To maintain electrostatic balance in plant cells, whenever a positive valence ion is absorbed, another one with the same valence is released, usually being $\mathrm{H}_{+}$, reducing the $\mathrm{pH}$ in the rhizosphere region, consequently compromising absorption of other nutrients.

Table 2 - Chlorophyll "a" (CLA), "b" (CLB) and total (TCL) and chlorophyll a / b (a /b) ratio of guaco plants grown in proportions of ammonium and nitrate $\left(\mathrm{NH}_{4}^{+}: \mathrm{NO}_{3}{ }^{-}\right)$.

\begin{tabular}{lllll}
\hline $\mathrm{NH}_{4}{ }^{+}: \mathrm{NO}_{3}^{-}$ & $\mathrm{CLA}$ & $\mathrm{CLB}$ & $\mathrm{TCL}$ & $\mathrm{a} / \mathrm{b}$ \\
\hline $100: 0$ & $32.40 \mathrm{c}$ & $10.27 \mathrm{c}$ & $42.67 \mathrm{c}$ & $3.15 \mathrm{a}$ \\
$75: 25$ & $35.59 \mathrm{bc}$ & $13.77 \mathrm{~b}$ & $49.35 \mathrm{~b}$ & $2.63 \mathrm{~b}$ \\
$50: 50$ & $37.89 \mathrm{ab}$ & $15.24 \mathrm{ab}$ & $53.13 \mathrm{ab}$ & $2.50 \mathrm{~b}$ \\
$25: 75$ & $39.69 \mathrm{a}$ & $17.26 \mathrm{a}$ & $56.95 \mathrm{a}$ & $2.30 \mathrm{~b}$ \\
$0: 100$ & $40.23 \mathrm{a}$ & $16.19 \mathrm{ab}$ & $56.42 \mathrm{a}$ & $2.50 \mathrm{~b}$ \\
\hline $\mathrm{CV}(\%)$ & 5.81 & 10.65 & 6.45 & 7.64 \\
\hline
\end{tabular}

Averages followed by the same letter in the column do not differ by the Tukey test $(p>0.05)$. CV: coefficient of variation.

Plants with reduced CLA, CLB, and TCL indexes received the treatment with the lowest ammonium content, showing that plants respond negatively to the supply of $\mathrm{N}$ exclusively by this ion in the solution. It is highlighted that chlorophyll increased due to increased absorption and incorporation of $\mathrm{N}$ in the nitric form. Thus, it is inferred that the $\mathrm{N}$ supply in the form of ammonium impairs $\mathrm{N}$ incorporation, decreasing chlorophyll content.

According to Silva et al. (2010), treatments with balanced $\mathrm{NH}_{4}{ }^{+}$and $\mathrm{NO}_{3}{ }^{-}$provide more $\mathrm{N}$, increasing productivity. Lewis (1989) said that better results are found for production of maize and wheat with the use of the two forms of $\mathrm{N}$ in the solution, being superior to using only one form. This event may be related to increasing $\mathrm{N}$ absorption dynamics in both forms.

Nitrate and ammonium can change chlorophyll levels, disturbing photosynthesis, as observed by Ruan et al. (2007) in Camellia sinensis. Conversely, Guo et al. (2012) found that N sources did not alter chlorophyll levels in Catharanthus roseus. N use in chlorophyll production can be a strategy of the plant to ensure adequate capture of light energy by photosystems (Taiz et al., 2017).

The highest $\mathrm{NH}_{4}^{+}: \mathrm{NO}_{3}{ }^{-}$ratios $(100: 0$ and $75: 25)$ had the lowest mean values of number of leaves, reducing this parameter in approximately $111 \%$ in relation to the 0:100 treatment. LA also decreased, with means of $3.05 \mathrm{~cm}^{2}$ and $5.70 \mathrm{~cm}^{2}$ in the $100: 0$ and $75: 25$ $\left(\mathrm{NH}_{4}^{+}: \mathrm{NO}_{3}{ }^{-}\right)$treatments, respectively (Table 3). According to studies by Sousa et al. (2010) on the effect of nitrate and ammonium in eggplant, the authors found a $45.6 \%$ reduction in the LA of seedlings fertilized only with $\mathrm{N}$ in ammoniacal form when compared to those submitted to a $72: 25\left(\mathrm{NH}_{4}^{+}: \mathrm{NO}_{3}^{-}\right)$ratio. 
Table 3 - Number of leaves (NL), leaf area (LA), specific leaf area (SLA) and leaf area ratio (LAR) of guaco plants grown in proportions of ammonium and nitrate $\left(\mathrm{NH}_{4}^{+}: \mathrm{NO}_{3}{ }^{-}\right)$.

\begin{tabular}{llccc}
\hline \multirow{2}{*}{$\mathrm{NH}_{4}{ }^{+}: \mathrm{NO}_{3}{ }^{-}$} & $\mathrm{NL}$ & $\mathrm{LA}$ & \multicolumn{1}{c}{$\mathrm{SLA}$} & $\mathrm{LAR}$ \\
\hline $100: 0$ & & $\left(\mathrm{~cm}^{2}\right)$ & $--------\left(\mathrm{cm}^{2} \mathrm{~g}^{-1}\right)$------ \\
\hline $75: 25$ & $18.2 \mathrm{~b}$ & $3.05 \mathrm{~b}$ & $2.86 \mathrm{c}$ & $1.11 \mathrm{c}$ \\
$50: 50$ & $27.6 \mathrm{ab}$ & $5.70 \mathrm{~b}$ & $3.21 \mathrm{bc}$ & $1.33 \mathrm{bc}$ \\
$25: 75$ & $35.4 \mathrm{a}$ & $10.38 \mathrm{a}$ & $3.79 \mathrm{abc}$ & $1.81 \mathrm{ab}$ \\
$0: 100$ & $38.4 \mathrm{a}$ & $13.83 \mathrm{a}$ & $4.36 \mathrm{a}$ & $2.05 \mathrm{a}$ \\
\hline $\mathrm{CV}(\%)$ & $35.6 \mathrm{a}$ & $13.90 \mathrm{a}$ & $4.05 \mathrm{ab}$ & $1.86 \mathrm{a}$ \\
\hline
\end{tabular}

When studying the effect of nitrate and ammonium on the growth and efficiency of $\mathrm{N}$ use in cassava, Cruz et al. (2006) observed that treatments consisting exclusively of nitrate or ammonium also reduced the number of leaves. The results above explain the reduced leaf dry mass obtained by these treatments.

The highest LA means were obtained using $\mathrm{NH}_{4}{ }^{+}: \mathrm{NO}_{3}{ }^{-}$ratios of $0: 100,25: 75$, and 50:50 (Table 3) in the nutrient solution. It should be noted that the treatment with only the application of ammonium obtained a lower value, which was related to the reduced LDM obtained for these same treatments. $\mathrm{N}$ is the main nutrient influencing leaf area and, consequently, photosynthetic rate, increasing dry mass accumulation in plants (Marschner, 2012). When the nitrogen source is not adequate, plants have their absorption impaired, with a performance similar to the deficit of this element.

For SLA, a mean of $4.36 \mathrm{~cm}^{2} \mathrm{~g}^{-1}$ was observed in the 25:75 $\left(\mathrm{NH}_{4}^{+}: \mathrm{NO}_{3}{ }^{-}\right)$ratio, not differing from means obtained in the $0: 100$ and 50:50 ratios and being superior to the other ratios (Table 3). Thus, the 25:75 $\left(\mathrm{NH}_{4}^{+}: \mathrm{NO}_{3}^{-}\right)$ratio increased leaf blade growth. For Peixoto et al. (2020), SLA increases are relevant, as they point to morphological adaptations that allow the plant to form a more efficient leaf area.

The LAR of Guaco plants was influenced by the ratios, with highest means in the 25:75, 0:100, and 50:50 $\left(\mathrm{NH}_{4}^{+}: \mathrm{NO}_{3}{ }^{-}\right)$ratios, which were superior to the other treatments (Table 3). This physiological index is very efficient to identify promising materials (Peixoto et al., 2020) and characteristics that, in the initial growth, increase the productivity of the adult plant, favoring studies in search for more productive materials.

It is possible to notice increased dry mass production in the plant with increasing nitrate ratios in the solution from $50 \%$ (Figure 1). The highest LDM means (3.4g; $3.18 \mathrm{~g}$ and $2.74 \mathrm{~g}$ ) were observed in Guaco plants grown in the 0:100, 25:75, and 50:50 $\left(\mathrm{NH}_{4}^{+}: \mathrm{NO}_{3}{ }^{-}\right)$ratios, respectively (Figure 1A). SDM accumulation was compromised using only ammonium as $\mathrm{N}$ source (Figure 1B). However, treatments containing nitrate ratios above $50 \%\left(0: 100\right.$ and $\left.25: 75 \mathrm{NH}_{4}{ }^{+}: \mathrm{NO}_{3}{ }^{-}\right)$differed from the others.

The ratios tested did not influence RDM accumulation (Figure 1D). For SHDM, it is noted that nitrate contributed with significant increases, with values of $5.62 \mathrm{~g} ; 5.20 \mathrm{~g}$, and $4.50 \mathrm{~g}$ reached at $0: 100,25: 75$, and 50:50 $\left(\mathrm{NH}_{4} 4^{+}: \mathrm{NO}_{3}^{-}\right)$ratios, respectively (Figure $1 \mathrm{C}$ ).

As with the other dry mass variables, SHDM was lower in treatments with predominance of ammonium as $\mathrm{N}$ source. Ammonium can negatively affect the stomatal conductance of the plant, directly interfering with transpiration and photosynthesis and compromising growth (Silva et al., 2010). Reduced SHDM increased the RSR $(0.59 \mathrm{~g})$ obtained in the treatment with $100 \%$ ammonium (Figure 1F). Similar results were described by Lima et al. (2018), who obtained the largest accumulations of biomass of Lippia alba (Mill) N. E. $\mathrm{Br}$ when $\mathrm{N}$ was supplied in nutrient solutions with $50 \%$ or more of nitrate. Thus, plants with increased ratios of ammonium ions have reduced dry mass accumulation.'

Similar results were obtained by Cruz et al. (2006), who reported that cassava plants grown only with ammonium in the solution had impaired growth. Rodrigues et al. (2016) also observed that increasing ammonium- $\mathrm{N}$ in the nutrient solution reduced LDM, SDM, RDM and, consequently, TDM in sage plants. According to the authors, the majority of plants absorb $\mathrm{N}$ preferably in nitric form. When $\mathrm{N}$ supply occurs in the ammonium form, absorption of other cations may be reduced due to a competitive effect and indirect, namely: increasing the activity of the $\mathrm{H}+$ proton in the solution due to exudation, favoring absorption of the $\mathrm{NH}_{4}{ }^{+}$cation.

In a study with sunflower submitted to ammonium and nitrate ratios, Alves et al. (2013) found that stem dry mass increased means when subjected to 0:100 and 25:75 $\left(\mathrm{NH}_{4}{ }^{+}: \mathrm{NO}_{3}{ }^{-}\right)$ratios, while ammonium reduced leaf and shoot dry mass.

When ammonium was supplied as the only $\mathrm{N}$ source, the lowest TDM accumulation $(2.75 \mathrm{~g})$ was observed (Figure 1E), with yield of approximately $37 \%$ in relation to the maximum production obtained in plants that received $\mathrm{N}$ only in nitrate form. This occurred because ammonium accumulation in the plant causes toxicity in plant cells (Taiz et al., 2017). In addition, $\mathrm{N}$ in ammonium form, in greater percentages, possibly affected the translocation of photoassimilates from shoot to roots (Lewis et al., 1989). 

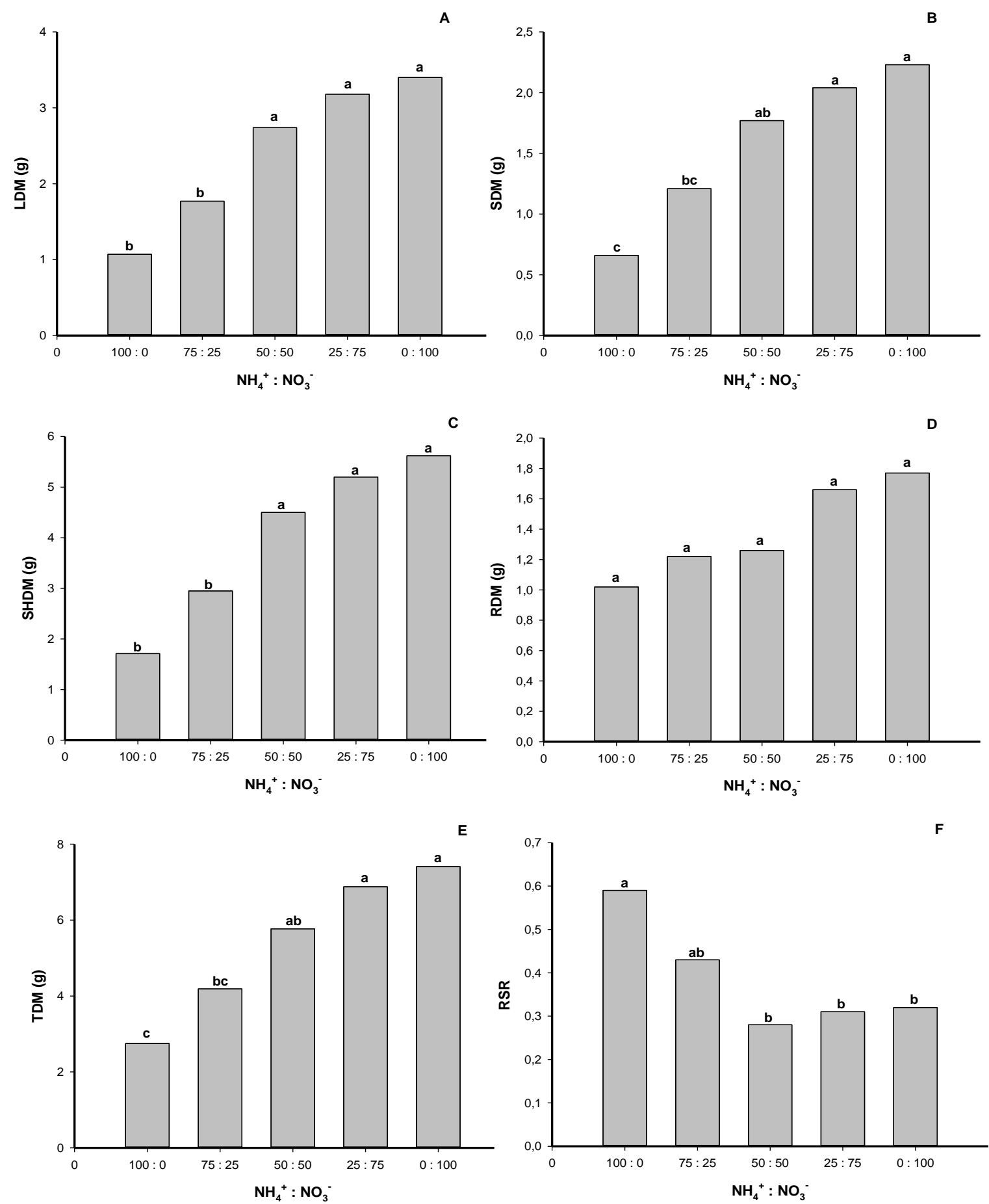

Figure 1 - Leaf dry matter mass (LDM), stem dry matter mass (SDM), shoot dry matter mass (SHDM) root dry matter mass (RDM), total dry matter mass (TDM), and aerial part root ratio (RSR) of guaco plants grown in proportions of ammonium and nitrate $\left(\mathrm{NH}_{4}^{+}: \mathrm{NO}_{3}{ }^{-}\right)$.

The treatments affected RSR, and ratios of 100:0, 75:25, and 50:50 $\left(\mathrm{NH}_{4}^{+}: \mathrm{NO}_{3}{ }^{-}\right)$did not differ from each other, being inferior than the other treatments, indicating that nitrate supply increased shoot dry mass because of no toxic effects associated with excessive accumulation of ammonium.

The highest ammonium concentrations compromised biomass accumulation, probably because the assimilation process of this ion requires the presence of carbon and energy skeletons, as to avoid toxic levels (Lewis et al., 1989).

\section{Conclusions}

The 25:75 $\left(\mathrm{NH}_{4}^{+}: \mathrm{NO}_{3}{ }^{-}\right)$ratio is the best for the biomass yield of Guaco plants. 
Increasing $\mathrm{N}$ ratios in the form of nitrate favor the initial growth of Guaco.

High ammonium ratios reduce the chlorophyll content in Guaco plants.

Guaco plants have their vegetative growth affected when grown with $\mathrm{NH}_{4}{ }^{+}$as the only source of nitrogen.

\section{Acknowledgment}

To the National Council for Scientific and Technological Development (CNPq) for granting financial support to research and to the ad hoc reviewers of this article for their valuable suggestions and corrections.

\section{References}

Aboy AL, Ortega GG, Petrovick PR, Langeloh A, Bassani VL (2002) Atividade antiespasmódica de soluções extrativas de folhas de Mikania glomerata Sprengel (guaco). Acta Farmaceutica Bonaerense 21(3):18591.

Ali A, Sivakami S, Raghuram N (2007) Effect of nitrate, nitrite, glutamate, glutamine and 2- oxoglutarate on RNA, levels and enzyme activities of nitrate reductase and nitrite reductase in rice. Physiology and Molecular Biology of Plants 13(1):17-25.

Alves AC, Jesus FN, Silva PC C, Santos AR, Souza, GS (2013) Diagnose nutricional de mudas de girassol submetidas a proporções de amônio e nitrato. Enciclopédia Biosfera 9:(16):723-731.

Bartelheimer M, Poschlod, P (2014) The response of grassland species to nitrate versus ammonium coincides with their pH optima. Journal of Vegetation Science 25(3):760-770, 2014.

Bittsánszky A, Pilinszky K, Gyulai G, Komives T (2015) Overcoming ammonium toxicity. Plant Science 231:184-190.

Campos SC, Silva CG, Campana PRV, Almeida VL (2016) Toxidade das Espécies Vegetais. Revista Brasileira de Plantas Medicinais 18(1):373-382.

Cruz JL, Pelacani CR, Araújo WL (2006) Efeito do nitrato e amônio sobre o crescimento e eficiência de utilização do nitrogênio em mandioca. Bragantia 65(3):467-475.

Czelusniak KE, Brocco A, Pereira DF, Freitas GBL (2012) Farmacobotânica, fitoquímica e farmacologia do Guaco: revisão considerando Mikania glomerata Sprengel e Mikania laevigata Schulyz Bip. ex Baker. Revista Brasileira de Plantas Medicinais 14(2):400-409.
Esteban R, Arz I, Cruz C, Moran JF (2016) Mechanisms of ammonium toxicity and the quest for tolerance. Plant Science 248:92-101.

Guo XR, Zu YG, Tang ZH (2012) Respostas fisiológicas de Catharanthus roseus a diferentes formas de nitrogênio. Acta Physiol Plant 34: 589-598.

Hachiya T, Watanabe CK, Fujimoto M, Ishikawa $T$, Takahara K, Kawal-Yamada M (2012) Nitrate addition alleviates ammonium toxicity without lessening ammonium accumulation, organic acid depletion and inorganic cation depletion in Arabidopsis thaliana shoots. Plant and Cell Physiology 53(3):577-591.

Helali SM, Nebli H, Kaddour R, Mahmoudl H, LachaâL M, Ouerghi Z (2010) Influence of nitrate-ammonium ratio on growth and nutrition of Arabidopsis thaliana. Plant and Soil 336(1):65-74.

Hoagland DR, Arnon DI (1950) - The water-culture method for growing plants without soil. California Agricultural Experimental Station. Circ. p. 347

Holzschuh MJ, Bohnen H, Anghinonl I, Pizzolato TM, Carmona FC, Carlos FS (2011) Absorção de nutrientes e crescimento do arroz com suprimento combinado de amônio e nitrato. Revista Brasileira de Ciência do Solo 35(4):1357-1366.

Huang, Lu Y, Gao X, Du G, Ma X, Liu M, Guo J, Chen $Y$ (2013) Ammonium induced oxidative stress on plant growth and antioxidative response of duckweed (Lemna minor L.) Ecological Engineering, 58: 355-362.

Lewis O A M, Leidi EO, Lips SH (1989) Effect of nitrogen source on growth response to salinity stress in maize and wheat. New Phytologist 111(2):55-160.

Lima JC, Oliveria UC, Santos AR, Souza, AA, Souza GS (2018) Proporções de amônio e nitrato no crescimento de plantas de Lippia alba (Mill) N. E. Br. cultivadas sob ambientes de luz. Revista de Ciências Agrárias 41(3):71-80.

Marouelli WA, Souza RB, Braga MB, Silva WLC (2014) Evaluation of sources, doses and application schedules of nitrogen on drip-irrigated tomato. Horticultura Brasileira 32 (3):327-335.

Marschner P (2012).Marschner's mineral nutrition of higher plants. 3. ed. San Diego: Academic Press, p.2012. 672.

Penido AB, Morais SM, Ribeiro AB, Silva AZ (2016) Ethnobotanical study of medicinal plants imperatriz, State of Maranhão, Northeastern Brazil. Acta Amazonica 46(4):345-344. 
Peixoto CP, Cruz TV, Peixoto MFSP (2011) Análise quantitativa do crescimento de plantas: Conceitos e Prática. Enciclopédia Biosfera 7(13):51-76.

Peixoto CP, Almeida AT, Oliveira ER, Santos JMS, Peixoto MFSP, Poelking VGC (2020) Princípios de fisiologia vegetal: teoria e prática. Rio de janeiro: Pod Editora, p.256.p.

R Core Team (2018) R: A language and environment for statistical computing. R Foundation for Statistical Computing. Disponível em <https://www.R-project.org/>. Acesso em 15 dez. 2019.

Rodrigues CR, Correia RM, Faquin V, Rodrigues TM, Sousa JB, Barbosa KP, Trindade PR (2016) Relação nitrato: amônia na nutrição mineral, crescimento e produção de óleo essencial da sálvia cultivada em solução nutritiva. Global Science and Technology 9(2):43-53.

Ruan JY, Härdter, R, Gerendas J, Sattelmacher B (2007) Effect of nitrogen form and root-zone ph on growth and nitrogen uptake of tea (Camellia sinensis) plants. Annals of Botany 99 (2), p. 301-310.
Silva CDS, Santos P AA, Lira JMS, Santana MC, Silva Junior CD (2010) Curso diário das trocas gasosas em plantas de feijão-caupi submetidas à deficiência hídrica. Revista Caatinga 23(4):7-13.]

Silva PCC, Couto JL, Santos AR (2010) Absorção dos íons amônio e nitrato e seus efeitos no desenvolvimento do girassol em solução nutritiva, Revista de Biologia e Ciências da Terra 10(2):97-104.

Sousa VFL, Oliveira FA, Oliveira FRA, Campos MS, Medeiros JF (2010) Efeito do Nitrato e Amônio Sobre o Crescimento da Berinjela. Revista Verde 5(3):80-88.

Taiz L, Zeiger E, Moller IM, Murphy A (2017) Fisiologia e Desenvolvimento Vegetal. 6 ed. Porto Alegre: ArtMed, p.888.

Yan L, Kustas WP, Huang C, Nieto H, Haghighi E, Anderson MC, Domingo F, Garcia M, Scott RL (2019) Evaluating Soil Resistance Formulations in ThermalBased Two-Source Energy Balance (TSEB) Model: Implications for Heterogeneous Semiarid and Arid Regions. Water Resource Research 55(2):1059-1078. 